\title{
Use of Value Driver Maps for Six Sigma Project Selection: A Case Study on Sales and Marketing for Soft Drinks Bottling Industry
}

\author{
Uso de mapas de dirección de valor para la selección de proyectos de Six Sigma: caso de \\ estudio en ventas y mercadotécnica para la industria embotelladora de bebidas carbonatadas
}

\author{
Sangabriel-Guillen Omar \\ Instituto Tecnológico y de Estudios Superiores de Monterrey, Campus Monterrey \\ Centro de Calidad y Manufactura \\ E-mail: osangabriel@gmail.com \\ Temblador-Pérez María del Carmen \\ Instituto Tecnológico y de Estudios Superiores de Monterrey, Campus Monterrey \\ Centro de Calidad y Manufactura \\ E-mail: mctemblador@itesm.mx \\ De la Rosa-Hernández Romina Marisol \\ Universidad Autónoma de Guadalajara \\ Posgrados de Sistemas de Calidad y Sistemas de Manufactura \\ E-mail: delarosa.romina@gmail.com
}

\begin{abstract}
The soft drinks bottling industry is one of the most successful industries in Mexico due to the high volume of consumption of these drinks. However, changes on the market such as the introduction of new competitors and state taxes have been producing a reduction on sales. In order to counter this effect, the sales and marketing functions of these organizations must improve their results and to do that they need to improve their processes. Six Sigma is a project driven methodology for process improvement that has been giving excellent results in the manufacturing environment, but its use for sale and marketing processes is seldom. This case study will provide an example of how it is possible to recognize Six Sigma projects by means of value driver maps for sales and marketing projects.
\end{abstract}

Keywords: Six Sigma, sales, marketing, project selection, value driver map, recognize.

\section{Resumen}

La industria embotelladora de bebidas carbonatadas es una de las industrias más exitosas en México debido al alto volumen de consumo. Sin embargo, los cambios en el mercado, tales como la introducción de nuevos competidores y los impuestos federales produjeron una reducción en las ventas. A fin de disminuir el efecto, las funciones de ventas y mercadotecnia de estas organizaciones deben mejorar sus resultados y hacer lo necesario para optimizar sus procesos. Six Sigma es una metodología para mejorar procesos, se ejecuta mediante proyectos que han dado excelentes resultados en manufactura, pero su uso en procesos de ventas y mercadotecnia es muy precario. Este caso de estudio proveerá un ejemplo de cómo es posible reconocer proyectos de Six Sigma mediante Mapas de Direción de Valor para proyectos de mercadotecnia y ventas.

Descriptores: Six Sigma, ventas, mercadotecnia, selección de proyectos, mapa de dirección de valor, reconocer. 


\section{INTRODUCTION}

Latin America represents one of the most important markets for manufacturers of carbonated drinks, as it concentrates the major consumers of soda in the world.

According to a study by Euromonitor International, Argentine is at top of the list with 131 liters per capita in 2012, followed by Chile with 121 liters and Mexico in third place with nearly 119 liters (CNN Expansión, 2013)

Carbonated drinks are considered a commodity and an essential part of the Mexican diet, providing energy to the working class as a milk substitute for the underprivileged children who consume it for its high sugar content. Therefore the bottling industry has been characterized for being stable as it keeps having a high sales volume even with the fluctuating conditions of the economy.

Before 2002, the carbonated drinks market in Mexico was divided mainly between two large bottler companies. Because of this characteristic, it could be considered as a duopoly. However, after 2002 a third bottler entered the Mexican market. The latter currently has two manufacturing plants and has been showing a significant increase in total market share. The market share for this third bottler is growing due to the introduction of the family size at lower price comparing with the current formats offered by the original two main bottling companies. As a result of this, market share was divided and the competition for market share has become fiercer (Sangabriel, 2012).

In addition to this, in 2013, Mexican Senate approved a reform that taxes one peso per liter of sugared beverages, as well as the related concentrates, powders, syrups, essences or flavoring extracts that contain any added sugars. These categories included carbonated drinks.

On average, the demand for carbonated drinks in Mexico decreased 4.06 percent (equivalent to 1.65 liters per person) during the first quarter, according to information provided by one of the main bottlers in Mexico. In 2013, per capita consumption of the carbonated beverage reached 163 liters per year. Meaning that, an average person in Mexico consumed nearly 40.75 liters per quarter (Espinosa, 2014). Thus, the sales goals of soft drinks in Mexico are much more difficult to achieve.

The goal of a company is to make profit. Thus, the reduction of sales is a major problem that must be solved in order to sustain the market share. The bottling companies require organized measures to face this reduction on sales, and because of that, is of the highest importance to improve the sales and marketing processes that are currently running on the organization. The potential impact of this strategy is that, by improving those processes, the results are shown directly on bottom-line profit (Pestorius, 2006).

This implies the necessity to establish a framework for problem solving that will provide a roadmap to make improvements on the sales and marketing processes. Today there are several problem solving methodologies that could address these kinds of problems, however it is necessary to pick one that has a structured thinking process that provides a common language and method to address business opportunities and solve business problems. A methodology that fits into this description is Six Sigma (SS).

SS has a history of success with hard savings. In the first 5 years of SS implementation, Motorola achieved saving of \$US 2.2 billion (Tohidi \& KhedriLiraviasl, 2012). For these reasons is safe to assume that this is the main driver for organizations to select SS as a solving problem methodology.

Six Sigma is a process improvement methodology, oriented to reduce variability of processes and with that, achieve defect (understanding a defect as any occurrence when a product or service does not satisfy the client's requirements) reduction or elimination based on data and facts through implementation of SS projects. According to Kubiak and Benbow (2009), SS could be defined on four different ways:

- Philosophy: The philosophical perspective views all work as processes that can be defined, measured, analyzed, improved and controlled. If you control the inputs, you will control the outputs.

- Set of tools: The SS expert uses qualitative and quantitative techniques to drive process improvement.

- Methodology: This view of SS recognizes the underlying and rigorous approach known as DMAIC (define, measure, analyze, improve and control). DMAIC defines the steps a Six Sigma practitioner is expected to follow, starting with identifying the problem and ending with the implementation of long-lasting solutions. While DMAIC is not the only SS methodology in use, it is certainly the most widely adopted and recognized.

- Metrics: In simple terms, SS quality performance means 3.4 defects per million opportunities (accounting for a 1.5-sigma shift in the mean).

From this point and onwards when Six Sigma is referred it would mean the methodology definition from the section above.

As written before, SS is implemented through SS projects. A typical SS project consists of the following 
phases Define, Measure, Analyze, Improvement and Control. Some variations were made to the DMAIC process in order to integrate the organizational goals (Recognize) and to assure the continuity of the improvement achieved with projects (Replicate/Review), transforming the process from DMAIC to R-DMAIC-R (Temblador y Beruvides, 2009).

The structure of the DMAIC methodology allows the use at any business function. Since the early days of SS, there has been an unfortunate but common perception that SS is only oriented to manufacturing processes and that a fact based problem solving methodology does not transfer well to transactional processes, such as sales and marketing (Pestorius, 2007).

The fundamental problem in these business functions is due to inefficiency or ineffectiveness of at least one component of the sales process or lack of information within the process (Webb, 2006).

Pestorius (2007) mentions several reasons for which people working outside manufacturing may be uneasy about using SS as a problem solving method, he lists the following:

1) In manufacturing it is believed that almost every variable can be controlled.

2) Professional backgrounds of SS consultants are usually from manufacturing areas, that may represent a barrier to the understanding of sales and marketing processes.

3) Quality is not an attribute typically measured in sales and marketing.

4) Sales and marketing do not easily adopt standardized processes.

However, Guaspari (2001) mentions that it is possible to implement SS on sales and marketing as long as the tools used on the methodology are tailored to these processes.

In Table 1, the differences between manufacturing and non-manufacturing on each of the DMAIC phases are presented.

SS is a project driven methodology. An adequate project selection is one of the most important activities because it guides the identification and allocation of resources in order to obtain more relevant benefits. One addendum to the DMAIC structure was the introduction of the Recognize before Define phase. At the Recognize phase, the customer, process and business voice are identified and along with the strategic planning they are used to align the company's objectives with the project list (Thompson, 2007). Pyzdek (2003) says that project selection for SS is as much as an art as a science. One starting point is to select projects that top management would "buy", however, there is no "ideal" procedure on how to select projects for SS, while there have been several attempts to make a process to select projects they fall short on how to do it constantly (Thompson, 2007).

This paper will present a framework for project selection in the sales and marketing environment and its results when applied to a soft drinks bottling company.

\section{Proposed framework}

Our proposed framework consists of the following stages:

I. Establish commitment and goals with Chief Marketing and Sales Officer (CMO) and his/hers staff.

II. Elaboration of a value driver map.

III. Project selection.

\section{Stage I. Establish commitment and With CMO}

SS as methodology could be used to improve business profitability, to drive out waste, to reduce cost of poor quality and to improve the effectiveness and efficiency of all operations so as to meet or even exceed customers' needs and expectations (Banuelas and Antony, 2002). In the past, this methodology has been predominantly used to improve manufacturing processes, but it is now increasingly applied to a wide variety of nonmanufacturing operations also known as transactional processes.

Most of the relevant transactional processes can be found in the sales and marketing functions. Selling and marketing exist because someone must persuade someone else to listen carefully, speak frankly, make a decision and typically part with his or her money (Webb, 2006). These functions (S\&M) must add value from a customer perspective.

As any business improvement strategy, SS requires commitment from top management also known as steering committee. Typically, each member of the steering committee will take the role of sponsor of the program, and therefore for a successful implementation they must be involved in the allocation of proper resources for the program (Halliday, 2001). One major key for this to happen is to have an executive training of the methodology prior to the beginning of the initiative.

Commitment often comes from the benefits (forecasted or previously obtained) of the implementation. Antony (2006) mentions the following benefits from applying Six Sigma on transactional processes: 
- Effective decisions must be taken based on facts instead of emotions. Costs can be considerable reduced using well-known techniques for problem resolution.

- Identify and appreciate the customers' requirements and expectations, it will influence the customer satisfaction and loyalty.

- The shareholders satisfaction will increase through trusted and capable internal operations.

- Problems could be efficiently solved implementing correct problem solving techniques and training.
- Discard systematically all the non-value operational activities in order to improve delivery of service.

- The level of service will be reliable by minimizing variability in service performance.

- Improve preventive process instead of fire-fighting approach.

- Encourage teamwork in all levels of the company

Once the management is convinced from the potential benefits, it is time to establish how to tackle sales and marketing problems. In order to address these pro-

Table 1. Differences between DMAIC phases for manufacturing and non-manufacturing

\begin{tabular}{|c|c|c|}
\hline Phase & Manufacturing & Non-manufacturing \\
\hline \multirow[t]{2}{*}{ Define } & $\begin{array}{l}\text { - Measurement of the process and product's } \\
\text { performance is business as usual }\end{array}$ & $\begin{array}{l}\text { - Development and application of quality } \\
\text { measurements it is regularly a great effort }\end{array}$ \\
\hline & $\begin{array}{l}\text { - Accountability falls under a specific manager } \\
\text { and is clear and explicit to achieve the objectives of } \\
\text { manufacturing }\end{array}$ & $\begin{array}{l}\text { - Accountability is frequently vague and therefore } \\
\text { the quality's goals are commonly unimportant }\end{array}$ \\
\hline \multirow[t]{4}{*}{ Measure } & $\begin{array}{l}\text { - Usually process maps or flowcharts exist before than a } \\
\text { SS project is begun }\end{array}$ & $\begin{array}{l}\text { - It is usual the absence of process maps or } \\
\text { flowcharts }\end{array}$ \\
\hline & $\begin{array}{l}\text { - Measurements are typically repeatable and it is } \\
\text { common in the measurement phase to perform a gauge } \\
\text { repeatability and reproducibility analysis }\end{array}$ & $\begin{array}{l}\text { - Measurements are typically not repeatable. } \\
\text { Sometimes the attribute analysis is required and } \\
\text { some others a measurement analysis is oriented more } \\
\text { in the reliability of the information rather than the }\end{array}$ \\
\hline & $\begin{array}{l}\text { - External customers often specify limits for quality } \\
\text { characteristics }\end{array}$ & measurement process itselt \\
\hline & & $\begin{array}{l}\text { - Specification limits are defined by internal goals } \\
\text { rather than external customers }\end{array}$ \\
\hline Analyze & $\begin{array}{l}\text { - Many factors are divided into two categories: } \\
\text { controllable (temperature, speed, etc.) or quantifiable } \\
\text { noise factors (shift-to-shift or machine-to-machine } \\
\text { differences) that can be classified as blocks }\end{array}$ & $\begin{array}{l}\text { - Uncontrollable or non-quantifiable factors are } \\
\text { typical }\end{array}$ \\
\hline \multirow[t]{3}{*}{ Improve } & $\begin{array}{l}\text { - Fractional factorial experiments to determine the } \\
\text { effects of factors on the quality characteristics are used }\end{array}$ & $\begin{array}{l}\text { - Experimentation is oriented to longitudinal studies } \\
\text { rather than transversal. It is required a fine-tuning on } \\
\text { experimental design for transactional processes }\end{array}$ \\
\hline & $\begin{array}{l}\text { - Improvements are made using direct changes on } \\
\text { controllable factors } \\
\text { - A mathematical transfer function is often obtained }\end{array}$ & $\begin{array}{l}\text { - Improvements are typically performed by } \\
\text { mitigating the impact of uncontrollable factors on the } \\
\text { process }\end{array}$ \\
\hline & & $\begin{array}{l}\text { - A mathematical transfer function is often not } \\
\text { explicitly developed }\end{array}$ \\
\hline \multirow[t]{2}{*}{ Control } & $\begin{array}{l}\text { - Quantitative methods of control are used such as } \\
\text { control charts, simulation models in contingency plans }\end{array}$ & $\begin{array}{l}\text { - Qualitative methods are used such as poka-yoke } \\
\text { devices, policy and procedure definition, etc. }\end{array}$ \\
\hline & $\begin{array}{l}\text { - FMEA is used as a validation tool on the effectiveness } \\
\text { and efficiency of the activities defined in measure/ } \\
\text { analysis phase }\end{array}$ & $\begin{array}{l}\text { - FMEA has more value in transactional processes } \\
\text { than in manufacturing due to the activities defined } \\
\text { for the highest scores of RPN are typically the inputs } \\
\text { for policy and procedure definition }\end{array}$ \\
\hline
\end{tabular}


blems, a value driver map is required to deploy, from the strategic down to the operative, performance indicators to be used that present an overview of S\&M functions.

\section{Stage II. Elaboration of a value driver map}

The goal of stage II is to identify the operative indicators ( $X^{\prime}$ 's) that have an impact on the Key Business Indicators $(\mathrm{KBI})$ that represents the process performance main result $(\mathrm{Y})$ through a value driver map (VDM). A VDM is a tree diagram that shows a relationship among strategic and operational performance indicators. An equivalent of the VDM is the CTQ tree that is used to translate needs considered vital by the customer into product and services characteristics and links these characteristics to organizational processes (Six Sigma Academy, 2002). The difference between VDM and CTQ tree is the focus on the processes and its result in the first one against the customer's needs in the second one. In the context of project selection for SS it is possible to use a value driver map to find which strategic indicators are the results (needs) of certain performance indicators (drivers) and which are the key issues to resolve in order to improve that performance (requirements) (Figure 1).

The process to elaborate a value driver map is the following:

1. At first, it is necessary to establish which is the main indicator to be improved. Usually a Key Business Indicator is selected, this indicator will be the " $\mathrm{Y}$ " of

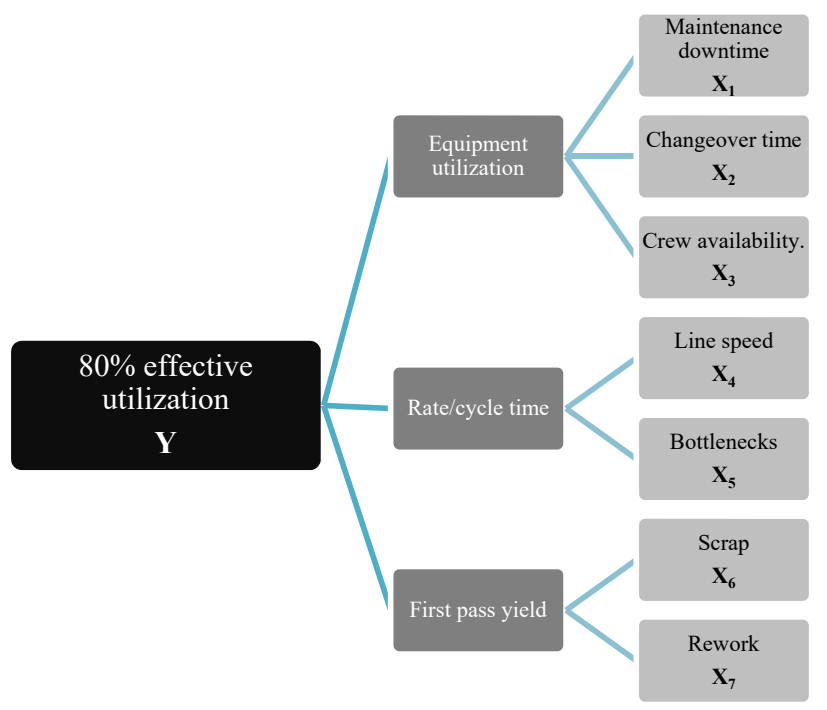

Figure 1. Indicators Value Driver Map the Value Driver Map and it should be place at the left of the sheet.

2. A participative session with stakeholders is required to define the components or elements that have impact on the " $Y$ " indicator. In order to do this, it should be asked how does $\mathrm{Y}$ is calculated? or what elements are required to estimate $Y$ ? This process would result on having on the right of the indicator another level for process performance indicators that have a relationship with the indicators on the left.

3. In order to ensure all indicators required are on the value driver map, a validation process is necessary before continuing to the next level. This should be done through a necessity and sufficiency analysis. Necessity means that the indicator is required in order to go to the next level and sufficiency would be when it is not needed another indicator to go to the next level. Once those two conditions are achieved it is safe to assume that is possible to go to the next level.

4. Step 2 and 3 repeat themselves until the last practical level is achieved (this is assured by step 3 ). The last level indicators are the ones that will be selected for the SS projects.

The deliverable for stage II will be a tree-like diagram (Figure 2) that establishes the relationship of the results (Y) with what it has been done on the processes (X).

\section{Stage III. Project Selection}

Project selection is a critical factor on any continuous improvement program, the correct identification of SS projects leads to significant benefits. Managers and employees gain This can induce confidence in management as well as in employees about the efficacy of the Six Sigma initiative, and as a result it will promote future investment and efforts in the initiative (Kumar et al., 2009).

There is research about the existing relationship of project selection and the stalling of such projects. There are two main reasons identified; 1 ) errors of problem definition traceable to the absence of certain objectively verifiable characteristics in the project itself, 2) errors in judgment during the decision-making process (Bacdayan, 2001).

The selection of six sigma projects is considered a multi-criteria decision where most of the information relevant to the problem is difficult and conflicting in nature. Selection criteria need to be prioritized so that those that are most critical to the overall success of the business will have the most impact on the project selection. 


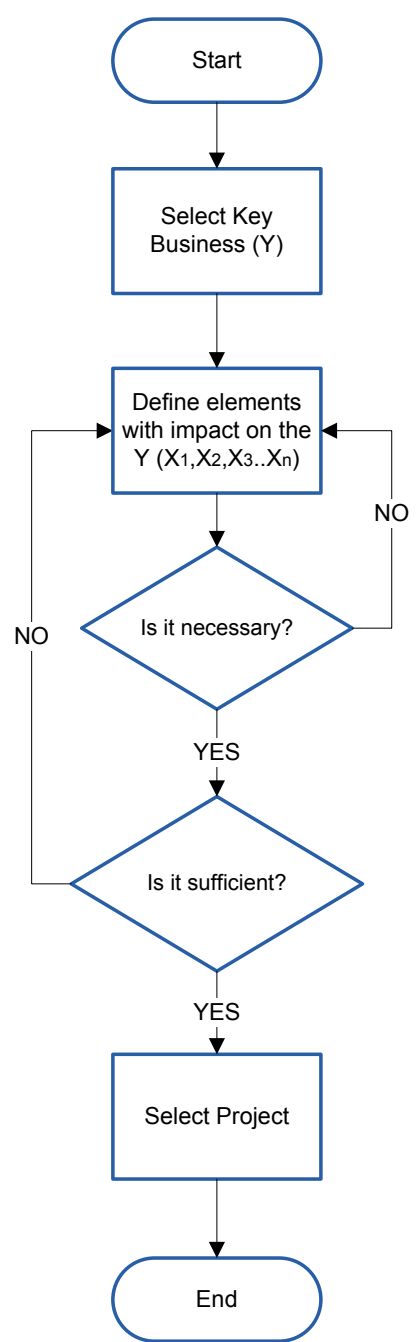

Figure 2.Flow chart for Stage II

The following table 2, is aligned with previous studies of critical success factors for six sigma implementation, where customer focus, linkage to business strategy, top management commitment and financial benefits are considered as essential factors for the successful implementation of six sigma (Banuelas et al., 2006; Antony, 2004).

At the end, management has to choose which of the criteria will be used for project selection. Usually they pick projects with higher financial impact; however as the company strategy could be one that focus in other aspects of the organization any criteria could be used.

Management should have an agreement on which criteria is to be used to avoid further questioning on why a project was selected.

At this point we have a Value Driver Map with the $X^{\prime}$ 's that affect our main indicator $(Y)$. Project selection shall be done by choosing from the pool of X's which are the ones that have a major impact according to the criteria agreed upon by management.

The project selected shall always have a form of "Increase/Decrease (depending on the indicator) $X^{\prime \prime}$. This is to ensure that there are no confusions on the objective of the project selected.

The selected projects should be evaluated later by the financial department to get an estimate of the benefits of each one of the projects. It is important that the evaluation specify what kinds of benefits will be resulting of completing the project (Direct P\&L savings, cost-avoidance, employee morale, etc.).

\section{CASE Study}

In order to implement this framework, we worked with a bottling company that was interested on doing process improvement projects for the sales and marketing function, so we were hired as External coaches.

At stage I, we met with the Chief Executive Officer (CEO) of the organization and its Sales and Marketing Director to establish the objectives of the implementation and who would be the team that would work on this particular SS implementation. The organization is structured as the figure 3 shown below.

Top management decided that for the first exercise to elaborate the value driver map a team formed by the Marketing Manager (1), Revenue Management Manager (1) and the Regional Sales Managers (4, one for each sales region) would be appropriate.

On the next meeting, the $\mathrm{CMO}$ and his staff were informed about the initiative of implementing SS on the Sales and Marketing functions, we discussed topics such as:

1) What is Six Sigma?

2) The benefits of using SS on Sales and Marketing and

3) Implementation Planning

Top management decided that the SS program objective was to be focused on two main directives: a) Increase Sales Income and b) Diminish Sales Expenses, the results would express a better performance on the Major Sales Indicator (Sales Income minus Sales Expenses). After this we scheduled a meeting for the following week to train the team to elaborate the value driver map.

For stage II, the session was scheduled with duration of 40 hours divided between 5 days. The agenda is indicated on Table 3.

On the opening, the $\mathrm{CEO}$ and $\mathrm{CMO}$ reassured the Implementation Team of the importance of the SS program to the company and how it would improve the company's revenue, they also expressed that SS imple- 
DOI: http://dx.doi.org/10.22201/fi.25940732e.2017.18n1.005

Sangabriel-Guillen Omar, Temblador-Pérez María del Carmen, De la Rosa-Hernández Romina Marisol

Table 2. Critical success factors for SS implementation. (Adapted from Banuelas et al., 2006)

\begin{tabular}{|c|c|c|c|c|c|c|}
\hline Critical criteria & $\begin{array}{l}\text { Customer } \\
\text { impact }\end{array}$ & Financial impact & $\begin{array}{c}\text { Top } \\
\text { management } \\
\text { commitment }\end{array}$ & $\begin{array}{l}\text { Measurable and } \\
\text { feasible }\end{array}$ & $\begin{array}{l}\text { Learning and } \\
\text { growth }\end{array}$ & $\begin{array}{c}\text { Connected } \\
\text { to business } \\
\text { strategy and } \\
\text { core competence }\end{array}$ \\
\hline $\begin{array}{c}\text { Harry and } \\
\text { Schroeder (2000) }\end{array}$ & $\nabla$ & $\nabla$ & & $\nabla$ & & - \\
\hline $\begin{array}{l}\text { Pande et al. } \\
\text { (2000) }\end{array}$ & $\nabla$ & $\nabla$ & $\nabla$ & $\nabla$ & $\nabla$ & $\nabla$ \\
\hline $\begin{array}{l}\text { Snee } \\
(2001)\end{array}$ & & $\nabla$ & & $\nabla$ & & $\nabla$ \\
\hline $\begin{array}{l}\text { Goldstein } \\
(2001)\end{array}$ & & $\nabla$ & & $\nabla$ & & \\
\hline $\begin{array}{l}\text { Breyfogle et al. } \\
\quad(2001)\end{array}$ & $\nabla$ & च & & $\nabla$ & & $\nabla$ \\
\hline $\begin{array}{c}\text { Pyzdek } \\
(2000,2003)\end{array}$ & $\nabla$ & च & & $\nabla$ & & $\nabla$ \\
\hline $\begin{array}{l}\text { Lynch and } \\
\text { Soloy (2003) }\end{array}$ & $\nabla$ & च & & $\nabla$ & & \\
\hline $\begin{array}{l}\text { Antony } \\
(2004)\end{array}$ & $\nabla$ & $\nabla$ & & & $\nabla$ & $\nabla$ \\
\hline
\end{tabular}

Marketing Manager Revenue Management Manager

Regional Sales Manager 1

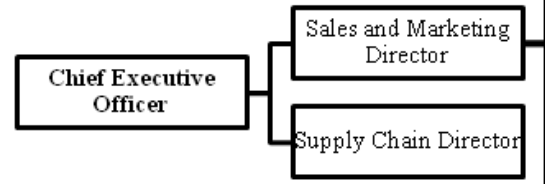

Regional Sales Manager 2

Regional Sales Manager 3

Regional Sales Manager 4

Figure 3. Organizational Chart

mentation would benefit the personnel skills and it was a good chance for exposure and career development. The team was reminded of the two directives that would have to be present on every project for the improvement of the Major Sales Indicator, they also were assured that they would have available resources to implement the projects.

After this we commenced the training for the team on Six Sigma, the topics covered were the basics of the R-DMAIC-R model, the objectives of each phase and which tools were to be used for implementation.
The next step was to train them on the Value Driver Map, this was done in order to do the exercise the next day, we asked them to bring information on their performance indicators to have the more data to work on.

In the exercise session, the team correctly identified the Major Sales Indicator as the Y on the Value Driver Map and on the next level the two directives that they were given on a previous session. This was followed by the questions, "Which are the main elements composing the Sales Income and the Sales Expense?" The session consisted on brain storming between managers and the review of the different performance indicators managed on their departments following the framework established on stage II. The resulting Value Driver Map is shown below as Figure 4.

The map was validated by the implementation team and in order to continue to stage III of the model. For the following day, the implementation team was asked to bring data on these KPI's. For stage III, each one of the Regional Sales Managers reunited with the Revenue Management Manager and the Marketing Manager and chose projects for each one of the regions. The criteria used to select the projects was financial impact. The number of projects selected was restricted by the number of people in their regions. In the table 4 below is shown the projects that were selected and the amount of people to deliver them. 
DOI: http://dx.doi.org/10.22201/fi.25940732e.2017.18n1.005

Use of Value Driver Maps for Six Sigma Project Selection: A Case Study on Sales and Marketing for Soft Drinks Bottling Industry

Table 3. Schedule for Stage II and III

\begin{tabular}{lll}
\hline \multicolumn{1}{c}{ Day } & \multicolumn{1}{c}{ Topics } & \multicolumn{1}{c}{ Participants } \\
\hline Monday & Opening & CEO \\
& Introduction to Six Sigma & $\begin{array}{l}\text { CMO } \\
\text { Implementation Team } \\
\text { External coaches }\end{array}$ \\
& Introduction to Six Sigma (Continuation) & $\begin{array}{l}\text { Implementation Team } \\
\text { External coaches }\end{array}$ \\
Wednesday & Value Driver Map Training & Implementation Team \\
& & External coaches \\
Thursday & Value Driver Map Elaboration & Implementation Team \\
& External coaches \\
Friday & Value Driver Map Elaboration & Implementation Team \\
& Project Selection & External coaches \\
& Team Selection & \\
& & CEO \\
& Closing & CMO \\
\hline
\end{tabular}

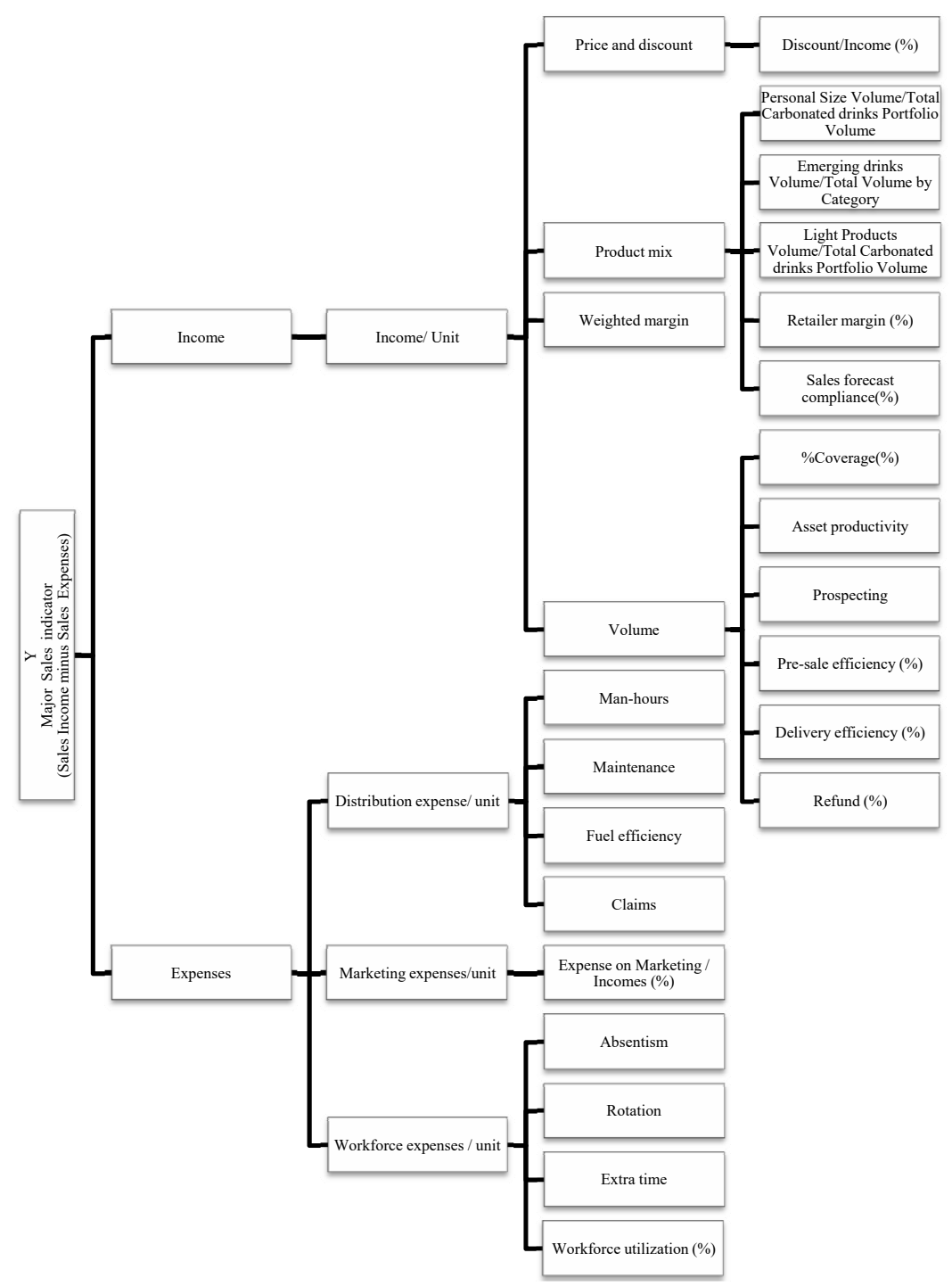

Figure 4. Value driver map for major sales indicator 
DOI: http://dx.doi.org/10.22201/fi.25940732e.2017.18n1.005

Sangabriel-Guillen Omar, Temblador-Pérez María del Carmen, De la Rosa-Hernández Romina Marisol

Table 4. List of selected projects

\begin{tabular}{|c|c|c|c|}
\hline Region & People & Project & Financial impact \\
\hline Region 1 & \multirow{3}{*}{8} & Increase asset productivity & $201,339.00$ \\
\hline Region 1 & & Increase fuel efficiency & $\$ 1,623,300.00$ \\
\hline Region 1 & & Increase pre-sale efficiency & $256,068.00$ \\
\hline Region 2 & \multirow{4}{*}{5} & Decrease vehicle rescues & $107,371.62$ \\
\hline Region 2 & & Increase delivery efficiency & $295,989.00$ \\
\hline Region 2 & & Decrease vehicle accidents & $145,245.78$ \\
\hline Region 2 & & Increase personal sizes volume & $467,192.00$ \\
\hline Region 3 & \multirow{5}{*}{7} & Increase fuel efficiency & $469,632.00$ \\
\hline Region 3 & & Increase pre-sale efficiency & $940,800.00$ \\
\hline Region 3 & & Increase personal sizes volume & $547,814.00$ \\
\hline Region 3 & & Increase emerging drinks volume & $48,352.00$ \\
\hline Region 3 & & Increase delivery efficiency & $618,512.00$ \\
\hline Region 4 & \multirow{3}{*}{15} & Increase personal size volume & $962,925.00$ \\
\hline Region 4 & & Increase emerging drinks volume & $\$ 3,206,684.00$ \\
\hline Region 4 & & Increase fuel efficiency & $857,328.00$ \\
\hline
\end{tabular}

After the projects were selected, Regional Managers would have to choose a start date for training on Six Sigma for each one the project leaders.

\section{Conclusions}

One of the hardest challenges that any continuous improvement program faces it is the lack of support from top management. Even today many organizations consider continuous improvement as a spend instead of an investment, on this type of organization a program is likely to fail on deliver results or simply fade away as another management initiative.

Six Sigma has proven in its many years of existence that is a project driven methodology that works and delivers real results, however much of its success depends on management support (time, people, financial resources, etc.) and the adequate project selection. Project selection is one of the most critical and challenging activities faced by Six Sigma companies. Most organizations are able to identify a host of project opportunities, but the difficulty arises in sizing and packaging those opportunities to create meaningful projects.

Top management often manages in the language of currency, while the processes measure its results on performance indicators. An effective communication between these two parts is crucial to achieve results that are on the benefit of the organization.

On the sales and marketing functions it is even more challenging to translate these requirements as most people believe that measurement on these areas is hard to achieve.

The value driver map is a straightforward tool that makes clear the relationship between processes and finances. In this way the proposed framework helps top management to have a notion of how an indicator has a certain impact over the bottom-line and therefore it is easier for them to continue supporting these initiatives. As the framework requires input from the main stakeholders it ensures that their expertise is rested on the relationships that are formed at each level of the map.

The use of these framework on the case study ensured that the top management main concern, the major sales indicator, was always the goal of the SS initiative and that all efforts were align to achieve such goal.

The outputs from the case study in this paper show that the value driver map approach provides an alternative way for selecting Six Sigma projects on sales and marketing functions. One advantage of the proposed framework is that it can be used on other key business areas of the organization without making any changes.

Furthermore, the proposed framework establishes a guideline to quantify and select projects based on impact on the bottom-line.

It is proposed as a further research to explore the possibility of creating mathematical models that could establish the relationship of indicators at its correspondent levels. This way an organization could predict what would be the impact of increasing or decreasing a performance indicator on the bottom-line. 


\section{RefERENCES}

Antony-Jiju. Six sigma in the UK service organisations: results from a pilot survey. Managerial Auditing Journal, volume 19 (issue 8), 2004: 1006-1012.

Antony-Jiju. Six sigma for service processes. Business Processes Management Journal, volume 12 (issue 2), 2006: 234-248.

Bacdayan P. Quality improvement teams that stall due to poor project selection: An exploration of contributing factors. Total Quality Management, volume 12 (issue 5), 2001: 589-598.

Banuelas R., Tennant Ch., Tuersley I., Tang S. Selection of six sigma projects in the UK. The TQM Magazine, volume18 (issue 5), 2006: 514-527.

Banuelas Coronado R. \& Antony-Jiju. Critical success factors for the successful implementation of six sigma projects in organizations. The TQM Magazine, volume 14 (issue 2), 2002: 92-99.

CNN Expansión [on line]. México, tercero en consumo de refrescos. Mexico City, April 8th 2013. [ref July 19th, 2014]. Available on: http://www.cnnexpansion.com/economia/2013/04/08/ al-lidera-el-consumo-mundial-de-refresco

Espinosa E. Baja compra de refrescos en el país. Dinero en imagen, May 10 th $^{\text {th }} 2014$ [ref: July 19, 2014]. Available on: http://www. dineroenimagen.com/2014-05-10/36986

Guaspari J. Six Sigma on sales. Across the Board, volume 38 (issue 5), 2001: 67-68.

Halliday S. So what exactly is Six Sigma? Works Management, volume 54 (issue 1), 2001: 15.

Kubiak T.M. \& Benbow D.W. The certified Six Sigma black belt handbook, $2^{\text {nd }}$ Edition, Wisconsin, Quality Press, 2009, ISBN 9780873897327

Kumar M., Antony J., Chong-Byung R. Project selection and its impact on the successful deployment of Six Sigma. Business Process Management Journal, volume 15 (issue 5), 2009: 669-686.

Pestorius M.J. Applying the science of Six Sigma to the art of sales and marketing, $1^{\text {st }}$ Edition, Milwaukee, USA, ASQ Quality Press, 2006, ISBN 9780873896962

Pestorius M.S. Six Sigma outside of manufacturing: Apply Six Sigma to sales and marketing. Quality Progress, 2007, 19-24.

Pyzdek T. The Six Sigma project planner, $1^{\text {st }}$ Edition, USA, McGrawHill, 2003, ISBN 9780071411837

Six Sigma Academy. The Black Belt Memory Jogger: A Pocket Guide to Six Sigma Success, Salem, NH: GOAL/QPC, 2002.

Temblador-Perez M.D. \& Beruvides M.G. Systems approach to problem solving using Six Sigma. American Society For Engineering Management Conference Proceedings, 2009, pp. 14-17.

Thompson-Steven J. Improving the performance of Six Sigma; A case study of the Six Sigma process at Ford Motor Company, Univeristy of Bedfordshire, 2007.

Tohidi-Hamid. \& KhedriLiraviasl-Kourosh. Six Sigma methodology and its relationship with lean manufacturing system. Advances in Environmental Biology, volume 6 (issue 2), 2012: 895-906
Webb M. Sales and marketing the Six Sigma way, Kaplan Publishing, 2006.

\section{BibLIOGRAPHY}

Banker-Rajiv D., Potter-Gordon, Srinivasan-Dhinu. Association of Nonfinancial Performance Measures with the Financial Performance of a Lodging Chain. Cornell Hospitality Quarterly, volume 46 (issue 4), 2005: 394-412.

Breyfogle F.W., Cupello J. \& Meadows B. Managing Six Sigma, 1st Edition, New York, USA, John Wiley \& Sons, Inc., 2001, ISBN 9780471396734

Dahlgaard-Jens J., \& Dahlgaard-Park-Su Mi. Lean production, six sigma quality, TQM and company culture. The TQM Magazine, volume 18 (issue 3), 2006: 263-281.

Does-Ronald, Heuvel-Edwin, Mast-Jeroen, \& Bisgaard-Soren. Comparing non-manufacturing with traditional applications of Six Sigma. Quality Engineering, 15(1), 2002, 177-182.

Falconi V. TQC Control de Calidad Total (al estilo Japonés). Belo Horizonte, Fundação Christiano Ottoni, 1992, pp.222.

Goldstein M. Six sigma program success factors. Six Sigma Forum Magazine, volumen 1 (número 1), 2001: 36-45.

Harry M. \& Schroeder R. Six Sigma: The breakthrough management strategy revolutionizing the world's top corporations, 1st ed., New York, USA, Doubleday, 2000, ISBN 9788129117731

Ittner C.D. \& Larcker D.F. Innovations in performance measurement: Trends and research implications. Journal of Management Accounting Research, volume 10, 1998: 205-238.

Ittner C.D. \& Larcker D.F. Coming up short on nonfinancial performance measurement. Harvard Business Review, volume 81 (issue 11), 2003: 88-95

Kennedy F.A. \& Brewer P.C. The Lean Enterprise and Traditional Accounting-Is the Honeymoon Over? Journal of Corporate Accounting \& Finance, volume 17 (issue 6), 2006: 63-74.

Lynch D. \& Soloy B. Improving the effectiveness of six sigma project champions, ASQ's Six Sigma Conference, 2003.

Maynard-Harold B., \& Zandin-Kjell B. Maynard's industrial engineering handbook, 5th Edition, New York, McGraw-Hill, 2001, ISBN 9780070411029

Pande P., Neuman R., Cavanach R. The six sigma way: How GE, Motorola, and other op companies are honing their performance, 1st ed., New York, USA, McGraw-Hill, 2000, ISBN 9780071358064

Parmenter D. Key performance indicators: Developing, implementing and using winning KPI's, 2nd Edition, Hoboken, New Jersey, John Wiley \& Sons, 2010, ISBN 978470545157

Pyzdek T. Selecting six sigma projects. Quality Digest, 2000, [on line] [Ref July 19, 2014]. Available on: http://www.qualitydigest.com/sept00/html/sixsigma.html

Rother M. \& Shook J. Learning to see: value stream mapping to add value and eliminate muda, 1st edition, Salem, New Hampshire USA, GOAL/QPC, 2002, ISBN 1576810437. 
Sangabriel O. Diseño y aplicación de una herramienta para el reconocimiento de oportunidades de mejora para la implementación de excelencia operacional, tesis (maestría en ciencias con especialidad en sistemas de calidad y productividad, $\mathrm{MCP}$ ) - Tecnológico de Monterrey, Monterrey, México, 2012, 156 pp.

Snee R. Dealing with the Achilles' Heel of six sigma initiatives project selection. Quality Progress, volume 34 (issue 3), 2001: 66-69.

\section{Citation for this article:}

\section{Chicago style citation}

Sangabriel-Guillen, Omar, María del Carmen Temblador-Pérez, Romina Marisol de la Rosa-Hernández. Use of Value Driver Maps for Six Sigma Project Selection: A Case Study on Sales and Marketing for Soft Drinks Bottling Industry. Ingeniería Investigación y Tecnología, XVIII, 01 (2017): 55-65.

\section{ISO 690 citation style}

Sangabriel-Guillen O., Temblador-Pérez M.C., De la Rosa-Hernandez R.M. Use of Value Driver Maps for Six Sigma Project Selection: A Case Study on Sales and Marketing for Soft Drinks Bottling Industry. Ingeniería Investigación y Tecnología, volume XVIII (issue 1), JanuaryMarch 2017: 55-65.

\section{AвOUt the AUthors}

Omar Sangabriel-Guillen. Bachelor in industrial engineering from Instituto Tecnológico de Veracruz (Veracruz, Veracruz-Llave) in 2009. He obtained his master of science in quality systems and productivity from Instituto Tecnológico y de Estudios Superiores de Monterrey (Monterrey, Nuevo León) in 2012. He was a senior operational excellence consultant for ITESM managing several continuous improvement projects and implementing Lean and SPC tools on several industries. His working experience has been on process improvement. His areas of research are process improvement and strategic planning. Currently he is QA Systems and CI Champion for an oil and gas company in Monterrey, Nuevo León.

María del Carmen Temblador-Pérez. Bachelor in industrial engineering from Instituto Tecnológico y de Estudios Superiores de Monterrey, PhD in in systems and engineering management at Texas Tech University, M.Sc. in quality systems and productivity and operations research at Instituto Tecnológico y de Estudios Superiores de Monterrey, B.S. Industrial engineering at Instituto Tecnológico y de Estudios Superiores de Monterrey. Actually works as the corporte liason director for the vinculation and extension direction at Instituto Tecnológico y de Estudios Superiores de Monterrey.

Romina Marisol De la Rosa-Hernández. Bachelor in industrial engineering from Instituto Tecnológico de Veracruz (Veracruz, Veracruz-Llave) in 2011. Currently she is pursuing a master of science in quality systems from Universidad Autonoma de Guadalajara (Guadalajara, Jalisco). Her area of research is process and quality improvement. Currently she manages several IT systems as well as quality assurance on IT projects for an energy sector company since May 2011, in Guadalajara, Jalisco. 